\title{
Pius IX in 1846-1848 - the Liberal Pope?
}

\section{K. A. Kimlenko ${ }^{1}$}

${ }^{1}$ Lomonosov Moscow State University, GSP-1 Leninskie Gory, Moscow 119991, Russian Federation

DOI: $10.18255 / 1996-5648-2021-4-526-531$

Research article Full text in Russian

The paper discusses the first years of the pontificate of Pius IX (1846-1878), when the newly elected head of the Catholic Church was perceived as a "liberal Pope”. On the one hand, in 1846-1848 Pius IX was the Pope who carried out reforms and announced an amnesty. On the other hand, in the same period he criticized rationalism and created censorship commissions. The paper is another attempt to answer the question whether Pius IX was indeed a "liberal" Pope at the beginning of his pontificate. Special attention is given to the Pope's policy during 1847. It was the time when the Papal States' population expected the continuation of the reform process. The paper raises the question of Cardinals' impact on the Pope, as well as on the pace of reform in the Papal States. Another key issue is the response of Pius IX to the revolutionary movement in Italy. The author concludes with the significance of the Pope's refusal to struggle against Austria for the further development of the process of Italian Unification.

Keywords: Pius IX; Papal States; Italy; reforms; revolutions of 1848-1849; neoguelfism

\section{INFORMATION ABOUT AUTHORS}

Kimlenka, Katsiaryna A. $\mid \begin{aligned} & \text { E-mail: k.kimlenko@gmail.com } \\ & \text { Postgraduate }\end{aligned}$ 


\title{
Пий IX в 1846-1848 гг. - папа-либерал?
}

\author{
Е. А. Кимленко ${ }^{1}$
}

${ }^{1}$ Московский государственный университет им. М. В. Ломоносова, Ленинские горы, д. 1, Москва, 119991, Российская Федерация

DOI: 10.18255/1996-5648-2021-4-526-531

УДК 94(450+456.31)

Научная статья

Полный текст на русском языке

В статье рассматриваются первые годы понтифриката Пия IX (1846-1878), когда новоизбранного главу Католической церкви и Папского государства воспринимали как «папу-либерала». С одной стороны, Пий IX в 1846-1848 гг. - это понтифик, который провел ряд реформ и объявил амнистию, а с другой - папа, который подверг критике рационализм, создал цензурные комиссии и отказался от перспективы возглавить итальянские государства в борьбе против Австрии. Статья представляет собой попытку ответить на вопрос, действительно ли Пий IX в начале своего понтификата был «либеральным» папой.

Ключевые слова: Пий IX; Папская область; Италия; реформы; революции 1848-1849 гг.; неогвельфизм

\section{ИНФОРМАЦИЯ ОБ АВТОРАХ}

Кимленко, Екатерина Александровна | E-mail: k.kimlenko@gmail.com Аспирант

История католической церкви полна примеров, когда после «консервативного» понтифика папскую тиару носил тот, кто имел славу «либерала». Шаги последнего, как правило, казались более прогрессивными на фоне курса его предшественника. В XIX в. эффект контраста в наибольшей степени проявился после смерти Григория XVI (1831-1846), когда на папский престол взошёл Пий IX (1846-1878).

Понтификат Григория XVI как светского государя оставил неблагоприятное впечатление у современников [1, p. 57]. 30-е - начало 40-х гг. XIX в. вошли в историю Папской области как время глубокого застоя в общественной жизни и экономическом развитии. Григорий XVI отказался от идеи создания Государственного совета, проведения рефрорм и даже от строительства железной дороги на территории Папской области [1, p. 51]. Результатом его консервативного курса стали беспорядки в ряде провинций Папского государства в первой половине 1840 -х гг. [2, р. 10]. В итоге стиль управления Григория XVI начали критиковать не только светские лица, но и кардиналы римской Курии [3, р. 51].

(с) Кимленко Е. А., 2021

Статья открытого доступа под лицензией CC BY (https://creativecommons.org/licenses/by/4.0/) 
Кимленко Е. А.

Несмотря на сложное отношение современников к Григорию XVI, широко распространенным являлось представление об особой исторической роли римского папы. Еще при жизни этого понтифика большие надежды возлагались на того человека, который станет его последователем на папском престоле. От него ожидали готовности возглавить борьбу жителей Апеннинского полуострова за освобождение Италии от австрийского господства и национальное объединение. Квинтэссенцией этих идей стала доктрина неогвельфизма, нашедшая свое выражение в труде аббата Винченцо Джоберти «О моральном и гражданском первенстве итальянцев» (1843 г.). Он утверждал, что папа должен возглавить объединенную Италию. По справедливому замечанию В. Е. Язьковой, «основную роль в разработке проекта конфедерации философр отводил Папскому государству и Сардинскому королевству, полагая, что именно от согласия между Римом и Турином зависит судьба Италии» [4, с. 96]. Идеи В. Джоберти получили дальнейшее развитие в сочинениях ряда политических мыслителей (Л. Галлеотти, Дж. Каппони, В. д’Эррико и др.) [3, р. 70].

После кончины Григория XVI перемены казались неизбежными. Среди кандидатов на папский престол на конклаве 1846 г. выделялся епископ Имолы Джованни Мария Мастаи Ферретти, известный критикой действий покойного папы [5, р. 36]. Его соперником был кардинал Л. Ламбрускини, Государственный секретарь Григория XVI, от которого ожидали продолжения курса предыдущего понтифика и сохранения благоприятного отношения к Австрии. Симпатии Коллегии кардиналов оказались на стороне Дж. М. Мастаи Ферретти, т. к. они надеялись, что ему удастся установить внутренний мир в Папском государстве [6, р. 86]. Кроме того, существовало мнение, что новым понтификом не должен стать кардинал, слишком сильно связанный с бюрократическим аппаратом Святого престола. Более предпочтительной выглядела кандидатура епископа Имолы, нежели Государственного секретаря Григория XVI [7, p. 141]. 16 июня 1846 г. Дж. М. Мастаи Ферретти был избран папой. Имя Пий IX он выбрал в честь Пия VII, одного из своих предшественников на посту епископа Имолы.

Восприятие Пия IX как «либерального» и «национального» папы, т. е. того, кто поддерживает независимость Италии, - это один из характерных социальных френоменов середины XIX в. На вопрос, был ли Пий IX действительно «либеральным», историография дает различные ответы. Известно, однако, что первые два года своего понтификата Пий IX по меньшей мере стремился соответствовать образу папы-новатора $[8$, p. 645]. Тем не менее реформы, проведенные им в 1846-1848 гг., имели весьма ограниченный характер и были во многом вынужденными. Однако на фроне атмосферы, царившей в Папском государстве в конце понтиориката Григория XVI, преобразования, которые осуществил его последователь на папском престоле, казались революционными и вызвали широкий общественный резонанс не только на Апеннинском полуострове, но и в Европе. 
16 июля 1846 г. папа объявил амнистию. Несмотря на то что амнистия касалась исключительно тех, кто совершил политические преступления, т. е. была ограниченной, она встретила весьма положительный отклик со стороны итальянских либералов. После амнистии, однако, папа не сразу предпринял схожий по своей значимости шаг.

Вноябре 1846г.ПийІХсформировалтрикомиссииизсветскихидуховных лиц, которые занимались изучением вопросов уголовного и гражданского судопроизводства, муниципальной системы и бродяжничества. 5 июля 1847 г. было объявлено о создании гражданской гвардии. Это означало, что впервые за столетия понтифик поручил защиту и сохранение порядка на территории своего государства местной милиции, а не только наемным войскам. 2 октября 1847 г. Пий IX распространил на Рим некоторые законы, уже применяемые в отношении других муниципалитетов Папского государства. В Риме он стал органом местной власти, наделенным конкретными полномочиями и связанным с новой формой представительства. В состав муниципального Совета входили 100 советников, из которых только четверо являлись священниками, назначаемыми кардиналом-викарием Рима. Выборы остальных проходили на основе имущественного и профессионального ценза [3, p. 139].

12 июня 1847 г. Пий IX учредил Совет министров с консультативными функциями. Его членами стали исключительно кардиналы и прелаты общественность выступала за проведение более глубоких реформ. В этой связи в конце 1847 г. папа решил включить в состав Совета министров светских лиц. Кроме того, в 1847 г. для разработки и обсуждения общественных преобразований Пий IX учредил Государственную Консульту, в состав которой должны были войти выдающиеся миряне, за исключением двух духовных лиц - ее президента и вице-президента.

В 1847 г. шли переговоры по проекту создания таможенной Лиги Тосканского герцогства, Сардинского королевства и Папского государства. Пий IX поддерживал идею создания Лиги, полагая, что она может стать стратегией, направленной на сдерживание и руководство процессом реформ в собственном государстве [6, p. 67]. Другими словами, Пий IX стремился сделать путь реформ настолько безопасным, насколько это было возможно.

В 1848 г., когда в Европе произошла целая серия революций, позиция Пия IX как светского государя стала менее прочной. Во многих итальянских государствах появились конституционные акты. Документ такого типа был опубликован и в Папской области 14 марта 1848 г. В соответствии с ним был создан избираемый Совет депутатов, который должен был предлагать законопроекты. Из его юрисдикции выводились церковные дела и вопросы, противоречащие канонам церкви [9].

Хотя первые годы понтификата были отмечены рядом реформ, однако Пий IX совершал шаги, которые вряд ли вписываются в образ «папылиберала». В первой энциклике Qui pluribus от 1 ноября 1846 г. он подверг критике религиозную индифферентность и рационализм [10]. Пий IX вернулся к церемонии «вступления во владение городом», которая казалась устаревшей. Она представляла собой конную процессию, сопровождавшую 
Кимленко Е. А.

новоизбранного папу $\mathrm{\kappa}$ базилике Сан-Джованни-ин-Латерано, его епископской кафедре. Обряд символизировал «многополярность власти папы» - правителя города, светского государя, епископа Рима и главы церкви $[6$, р. 39]. $К$ шагам Пия IX, которые не соответствовали представлениям современников о папе-новаторе, относился также закон о печати (март 1847 г.). Он предполагал создание цензурных комиссий во всех основных городах Папской области и в Риме [2, p. 12]. В Риме реакция на этот шаг Пия IX была особенно негативной: на копиях, прикрепленных к городским стенам, вскоре появились гербы покойного Григория XVI $[11$, p. 64]. Современники полагали, что закон о печати был таким же консервативным, как законы предыдущего понтификата.

Когда линия Пия IX перестала полностью соответствовать образу «папы-либерала», то во время народных выступлений стали слышны крики не "Viva Pio IX" («Да здравствует Пий IX»), a "Viva Pio IX solo" («Да здравствует только Пий IX») [2, р. 14]. Последняя формула как бы противопоставляла папу-реформатора кардиналам-ретроградам. В. Джоберти в своей брошюре «Обращение католического философра к Пию IX» (1847 г.) также указывал на то, что кардиналы не поддерживают Пия IX в его стремлении реформировать Папское государство. При этом он верил в то, что папа, несмотря на это обстоятельство, преуспеет в изменении существовавшего политического порядка: «Напрасно некоторые малодушные, прославляя Ваши, Святейший Отец, добродетели и намерение творить добро, пытаются поставить под сомнение их [реформ. - aвm.] успех, говоря, что Вы одиноки в своих стремлениях» [12, p. 9]. В целом на протяжении 1847 г. представление о том, что консервативно настроенные кардиналы препятствуют углублению реформ, продолжало укрепляться среди населения Папского государства.

Среди ближайшего окружения папы наиболее одиозной персоной считался кардинал П. Джицци, Государственный секретарь Пия IX в 1846-1847 гг. Когда папа назначил его на этот пост, то общественность рассчитывала, что он будет следовать умеренной линии, далекой от консерватизма Государственного секретаря Л. Ламбрускини. Однако вскоре стало очевидно, что П. Джицци выступает против проведения реформ. Он подверг критике идею создания гражданской гвардии. Кардинал понимал, что участники многочисленных демонстраций в поддержку Пия IX не просто прославляли папу, но и ожидали от него более значительных реформ и даже введения конституции. По этим причинам П. Джицци всячески пытался сократить количество демонстраций, если не запретить их вовсе [13, p. 190]. Сам Пий IX чётко осознавал, что благосклонность населения Папского государства к его фигуре связана с ожиданием углубления реформ и упованием на ведущую роль понтифика в борьбе итальянцев за национальное единство. Он писал в марте 1847 г. кардиналу Л. Амату, что «надежды питают эту привязанность» [11, p. 44].

Речь Пия IX Non semel 29 апреля 1848 г. положила конец идее о создании конфедерации во главе с папой. Пий IX отказался от войны против Австрии и от перспективы возглавить конфедерацию итальянских госу- 
дарств. Он заявил, что будучи «отцом всех верующих», он не может вести войну с христианским народом [14]. Эта позиция Пия IX привела к резкому падению его популярности в итальянских государствах и ознаменовала собой переход инициативы от неогвельфов к неогибеллинам в процессе объединения Италии. Недостаточно глубокие реформы Пия IX были подвергнуты жесткой критике представителями революционно-демократического крыла Рисорджименто. Проблемой для Пия IX оказалось и то, что в условиях подъема национально-освободительного движения процесс реформ было сложно остановить.

В целом шаги, предпринятые Пием IX в 1846-1848 гг., не следует воспринимать как согласие с идеей постепенного обмирщения государственного механизма и стремление радикально изменить Папское государство. Рефрормы начала понтификата скорее являлись попыткой провести ограниченные по своему характеру преобразования как с целью сохранения духовного влияния папы в Европе, так и геополитического присутствия Папского государства на полуострове.

\section{Ссылки}

1. Chadwick O. A. A History of the Popes 1830-1914. New York, 1998. 624 p.

2. Ara A. La fase liberale e riformatrice di Pio IX (1846-1848) // Pius IX. und der Kirchenstaat in den Jahren 1860-1870: Ein deutsch-italienisches Kolloquium. Erlangen, 1995. P. 9-25.

3. Martina G. Pio IX (1846-1850). Roma, 1974. 566 p.

4. Язькова В. Е. Пий IX: от «папы-либерала» к «узнику» либерального государства // Вестник Литературного института им. А. М. Горького. 2013. № 2. С. 95-108.

5. Maioli G. Pio IX da vescovo a Pontefice. Modena, 1949. 138 p.

6. Veca I. Il mito di Pio IX. Storia di un papa liberale e nazionale. Roma, 2018. 309 p.

7. Chiron Y. Histoire des conclaves. Paris, 2013. 276 p.

8. Carnevale M., Caracciolo A. Lo Stato Pontificio da Martino V a Pio IX. Torino, 1978. $793 \mathrm{p}$.

9. Statuto fondamentale del governo temporale degli Stati di Chiesa Pio PP. IX // Università degli Studi di Torino. URL: http://www.dircost.unito.it/cs/docs/chiesa1848. htm (accessed: 05.09.2020).

10. Qui Pluribus Enciclica del Sommo Pontefice Pio IX // La Santa Sede. URL: http://www.vatican.va/content/pius-ix/it/documents/enciclica-qui-pluribus-9novembre-1846.html (accessed: 05.09.2020).

11. Quazza R. Pio IX e Massimo D’Azeglio nelle vicende Romane. Modena, 1954. Vol. 1: Dalle questioni interne al problema nazionale (da documenti ineditti). 177 p.

12. Gioberti V. Discorso di un filosofo cattolico a Pio IX P.O.M. Roma, 1847. 15 p.

13. Martina G. I segretari di Stato di Pio IX // Mélanges de l’École française de Rome. Italie et Méditerranée. 2004. T. 116, No. 1. P. 189-197.

14. Allocuzione Non Semel del Sommo Pontefice // La Santa Sede. Pio IX. URL: http://www.vatican.va/content/pius-ix/it/documents/allocuzione-non-semel-29aprile-1848.html (accessed: 10.10.2020). 